\title{
Principles and methods of calculating hybrid contactors of direct current, controlled by an electric drive current
}

\author{
A.Soskov \\ O.M. Beketov National University of Urban economy \\ in Kharkiv, \\ Ukraine \\ E-mail: ansoskov@gmail.com
}

\author{
O.Iegorov \\ O.M. Beketov National University of Urban economy in \\ Kharkiv, \\ Ukraine \\ E-mail: diaskk67@gmail.com
}

\author{
Ya.Forkun \\ O.M. Beketov National University of Urban economy \\ in Kharkiv, \\ Ukraine \\ E-mail: jana.forkun@gmail.com
}

\author{
Yu. Kolontaevsky \\ O.M. Beketov National University of Urban economy in \\ Kharkiv, \\ Ukraine \\ E-mail: yuri_kolontaevsky@kname.edu.ua
}

\begin{abstract}
It has been shown that the principle of controlling the current of an electromagnetic drive of a hybrid contactor of direct current is realized by introducing a special control electric circuit in parallel with a drive coil by means of turning on a power SK (semiconductor key), which contains a condenser, setting the time and controlled low-power transistor key, in an output circuit of which a low-power optron thyristor is included, moreover, an auxiliary transistor key, providing the current discharge with the help of additional secondary electric winding when commutation current flows from the circuit of the main contactors to the circuit of a power semiconductor key, is turned on in parallel to the mentioned condenser.
\end{abstract}

The peculiarities of the processes of charging and discharging of a condenser, which sets the time, in different operating conditions of a contactor, have been determined. Whereby, it has been found out that for providing reliable circuits commutation it is necessary that a condenser charging time, setting the time up to the level of voltage, providing turnon of a low-powered optron thyristor when a contactor is turned on, shouldn't exceed the value of minimum time of its turn-on and the time of the condenser discharge when turned off shouldn't be lower than the minimum time of a contactor turn-off. It allows to determine the parameters of the elements, providing reliable commutation of a contactor.

As a result of the research it has been shown that the proposed hybrid contactors due to the introduction of electromagnetic drive current control and new connections as compared with the existing ones, possess the properties increasing their competitiveness. They also have increased operation reliability, reduced dimensions and cost, their production and technological indices are improved and the sphere of their application is broadened.

The possibility of creating competitive reliable hybrid contactors of direct current on the currents 100-630 $\mathrm{A}$ and voltage up to $1000 \mathrm{~V}$, which function in hard maintenance conditions, is considered to be an applied aspect of putting into practice the research results obtained.
Key words - hybrid contactor, direct current, main contacts, power semiconductor key, current control, electromagnetic drive. TARGET SETTING

Hybrid contactors of direct current or contactors with arcless commutation combine positive qualities both of contact apparatuses (small loses of power in on position), and non-contact ones (arcless current commutation). In these contactors parallel to the main contactors of the base contactor, as a rule, with electromagnetic drive, completely controlled power semiconductor key (SK) is connected, providing arcless commutation of disconnecting contacts. Its turn-on and turn-off is made the control circuit. In on position of a contactor a completely controlled SK is bypassed by the main contacts. So, SK is under the load just for a short period of time (some ms) at loading commutation allowing to use completely controlled power semiconductor devices (PSD) (IGBT-transistors: GTO- thyristors etc) without coolers using natural cooling when constructing SK. Besides, the use of a blowout system of the base contactor is not necessary. It is very important for contactors intended for the net voltage of higher than $500 \mathrm{~V}$, when the commutation process of inductance loading becomes complicated.

As a result, commutation wear resistance of hybrid contactors increases dozens of times and approaches the mechanic one when an apparatus mass is a bit increased (up to $20-30 \%$ ). However, in the case of using expensive completely controlled power SK in these contactors, their price is two times or [1] or higher than of common classical contactors.

That is why, from the technical and economic point of view, they should be used in hard maintenance conditions, characterized by frequent commutations of active and inductance loading and in conditions of increased explosion and fire safety requirements.

\section{INTRODUCTION. URGENCY OF THE RESEARCH AND}


Nowadays, the sphere of using hybrid commutation apparatuses (including contactors) of direct current widened greatly due to the development of direct current nets, in which renewable sources of electric power are used (solar and wind power stations) $[3,4]$.

In connection with that the works, aimed at the development of new principles of creating hybrid commutation apparatuses and methods of their calculation, providing the increase of their competitiveness at the world market of electro-technical products, are urgent and in demand. The review of scientific works for a period of 10 years is given by the authors in [5] and shows that such research work is carried out worldwide [6-8].

\section{THE AIM AND THE TASKS OF THE RESEARCH}

The aim of the research is to develop the principles and methods of calculating operating conditions and parameters of hybrid contactors of direct current (with an electromagnetic drive), controlled by the electric drive current.

The following tasks are to be solved:

To prove that the principle of controlling a hybrid contactor by the current of its electromagnetic drive allows to increase its competitiveness as compared with the existing ones;

To study nonstationary electromagnetic processes, providing electromagnetic drive current control by a contactor;

To elaborate the methods of calculating electronic circuit elements, providing electromagnetic drive current control and to give recommendations on the choice of their parameters and operating conditions.

\section{TECHNICAL SOLUTIONS ON CREATING HYBRID} CONTACTORS OF DIRECT CURRENT AND THEIR ANALYSIS

Technical solutions in the form of an electric circuit of a two-pin hybrid contactor of direct current, controlled by the current of its electromagnetic drive, have been worked out at O.M. Beketov National university of urban economy in Kharkiv (Ukraine, Kharkiv). This principle is realized in such a way that a special electronic circuit of control with a condenser, setting the time, and a controlled transistor key with an optron thyristor connected with its input circuit, is introduced in series with the coil of electromagnetic drive. This circuit provides reliable contactless turn-on and turnoff of a completely controlled SK, as the main contactor contact is by-passed when the loading is commutated by an apparatus. The main technical solutions, applied in the contactor, are protected by patent [9.10].

An electric circuit of the given contactor is presented in figure 1.

A classical double-pole contactor with an electromagnetic drive is applied as the base contact apparatus.

Such elements of a contactor as the main contacts $M C 1$ and $M C 2, I G B T$-transistor $V T 3$ with a reverse diode $V D 7$, primary coils $W 1.1, W 1.2$ of a current transformer $T A 1$ form the main circuit of a contactor on the circuit. At the same time the contacts 1 and $2 M C 1$ and $M C 2$ are adjusted in such a way that the second contact is broken later than the first one (time latency is 8-9 ms), and instead of IGBT-transistor a dual-operation thyristor can be applied.

A thyristor block $R_{8}$ is intended for spilling the power accumulating in a circuit inductance, and an optron thyristor $V S 3$ - for spilling the power accumulated in a loading inductance. The latter element allows to use the proposed contactor in non-reverse circuits. The rest elements form the circuit of controlling the commutation of the main contacts or VT3.

Such elements as the button START and STOP, auxiliary contacts $M K 1.1$ and the coil of electromagnet $M K 1$ provide a drive control and thus the commutation of the main contacts.

Such elements as a diode bridge (VD1 - VD4), a condenser $C 1$, setting the time, a transistor $V T 2$, optron thyristor $V S 1$, resistors $R_{4}-R_{9}$, a condenser $C_{2}$, a voltage regulator $V D 6$ and a bilateral voltage selector $V D 8$ provide turn-on of a transistor VT3 (or a dual-operation thyristor). In their turn, such elements as a transistor $V T 1$, resistors $R_{1}$ $R_{3}$, a diode $V D 5$, secondary coils $W 2.1$ and $W 2.2$, diodes $V D 9$ and $V D 10$, a commutating condenser $C_{3}$, a commutating thyristor $V S 2$, resistors $R_{10}$ and $R_{11}$, an input circuit of an optron thyristor VS3 provide turn-off $V T 3$ (or a dual-operation thyristor).

While a contactor is powered off all elements of its electronic circuit are de-energized and in on-position just a small amount of elements, included into the circuit of an electromagnetic drive, are under load.

A detailed description of a contactor work is presented in $[9,10]$.

As can be seen from the analysis presented in $[5,9,10]$, the technical solutions proposed by the authors allow to create hybrid contactors, providing reliable arcless commutation both in on-position and when powered off. They don't need the use of costly large standard driver with a special power unit as well as an additional source of power. Furthermore, as compared with the existing contactors, they possess the following additional positive characteristics:

1) Increased operation reliability, provided by the following factors: excluding of a less-than-perfect contact circuit, created on the basis of a current relay, from the controlling circuit of a power SK, complete excluding of a possibility of an emergency restart of a power SK upon power failure, and economical operating conditions of the elements of a contactor electronic circuit as well as excluding of a voltage influence on the elements of a controlling circuit;

2) Reduced dimensions, mass and cost due to considerable simplification of a controlling circuit (excluding of the time relay and a large non-process current relay, simplification of the connections between the electric contacts);

3) The parameters and operating conditions of the circuit controlling an electrical part don't depend on the net voltage and are determined only by the turned off current, it allows to use the proposed technical solutions also for creating hybrid contactors for the voltage higher than 1000 $\mathrm{V}$; 
4) The absence of the commutation zone with an arc increases its commutation durability as well as allows to apply it in conditions of strict explosion and fire safety requirements.
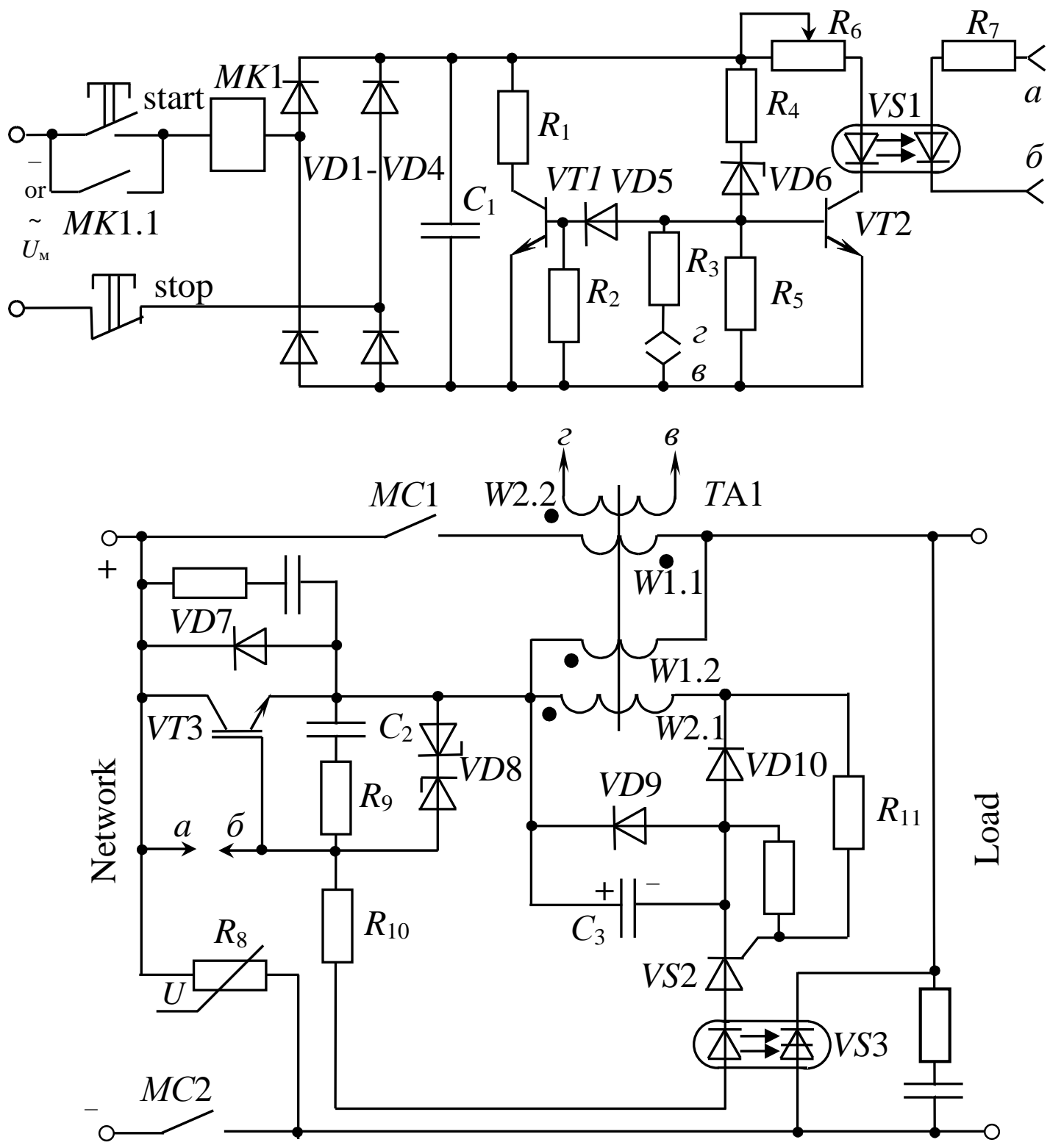

Fig. 1. Hybrid double-pole electromagnetic contactor of direct current controlled by an electric drive current

The properties mentioned above essentially increase the competitiveness of the proposed contactor due to the increase of the maintenance properties and production simplification.

For substantiation of the results obtained and for providing practical realization it is necessary to study the processes which haven't been considered before, but occurring in a contactor circuits in case of loading commutation. On the basis of the data obtained the necessary calculation techniques are expected to be worked out.

\section{THEORETIC RESEARCHES OF NONSTATIONARY}

PROCESSES IN THE CIRCUITS OF HYBRID CONTACTORS

The data of the researched processes are presented below. The main processes occur in the circuit of electromagnetic drive of a contactor in case of its commutation. The design circuit for studying these processes is presented in figure 2 .

The following symbols are used in the circuit:

- $R_{k}$ - active resistance of a drive coil;

- $L_{k}$ - inductive resistance;

- $C_{1}$ - condenser connected with a coil in series;

- $R_{6}$ - regulated resistor, connected with the input circuit of the optron thyristor;

- $V T 2$ - transistor key; 
- $V D 1$ - threshold voltage regulator, determining the voltage level on the condenser, on which the turn-on of the key VT2 occurs.

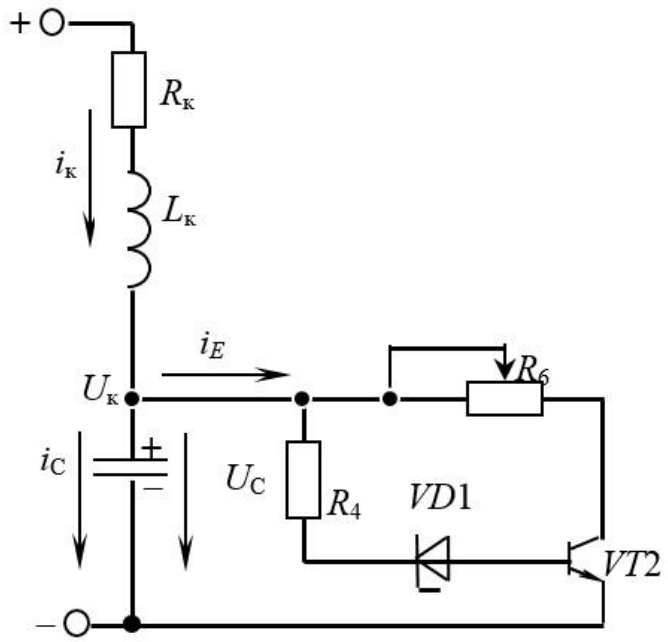

Fig.2. Design circuit for studying the processes occurring in the circuit of an electromagnetic drive

As the resistor resistance $R_{4}$ is enormously higher than that of the resistor $R_{6}$ (in modern low power transistors the coefficient of the current transmission $\beta>100$ ), it is possible to consider with a fractional error that the equivalent value of resistance, connected in parallel to the condenser $C_{1}$, will be the following $-R_{\mathrm{E}}=R_{6}$.

The process of charging a condenser $C_{1}$ in case of a turned on contactor is divided into two stages. The first stage lasts up to the moment of turning on a transistor key VT2, i.e. up to the voltage reaches the voltage value of the breakdown of the regulator $V D 1$. In this case a transmission process in the circuit is determined with the following equation:

$$
u_{k}=i_{k} \cdot R_{k}+L_{k} \cdot \frac{d i_{k}}{d t}+u_{C}
$$

After the corresponding transformations we have:

$$
\frac{d^{2} u_{C_{1}}}{d t^{2}}+\frac{R_{k}}{L_{k}} \cdot \frac{d u_{C_{1}}}{d t}+u_{C} \cdot \frac{1}{L_{k} \cdot C_{1}}=\frac{U_{k}}{L_{k} \cdot C_{1}}
$$

According to [11] its solution looks like that:

$$
\begin{gathered}
u_{C}=U_{K}+\frac{U_{K}}{p_{1}-p_{2}} \cdot\left(p_{2} \cdot e^{p_{1} \cdot t}-p_{1} \cdot e^{p_{2} \cdot t}\right), \\
i_{K}=\frac{U_{K}}{L_{k} \cdot\left(p_{1}-p_{2}\right)} \cdot\left(e^{p_{1} \cdot t}-e^{p_{2} \cdot t}\right)
\end{gathered}
$$

where

$$
p_{1,2}=-\frac{R_{K}}{2 \cdot L_{k}} \pm \sqrt{\left(\frac{R_{K}}{2 \cdot L_{k}}\right)^{2}-\frac{1}{L_{k} \cdot C_{1}}}
$$

In this case it is supposed that a charging process is aperiodic, i.e. $\left[\left(\frac{R_{K}}{2 \cdot L_{k}}\right)^{2}-\frac{1}{L_{k} \cdot C_{1}}\right]>0$

The second stage starts from the moment of turning on a transistor key $V T 2$ in case of a regulator breakdown $V D 1$. In such case $\left(R_{\mathrm{E}}=R_{6}\right)$;

$$
U_{C}(0)=U_{C T}, I_{7}(0)=\frac{U_{C T}}{R_{E}} \geq I_{\text {turn-onvS } 1}
$$

where $U_{\mathrm{CT}}$ - the voltage of the regulator breakdown $V D 1$,
$R_{\mathrm{E}}=R_{6}$, $1)$.

$\mathrm{I}_{\text {turn-onVS1 }}$ - turning on current of optron thyristor VS1 (fig.

For determining the time of a transistor key closing $\left(\mathrm{t}_{1}\right)$ it is necessary to solve the following transcendental equation:

$$
U_{C T}=U_{k}+\frac{U_{k}}{p_{1}-p_{2}} \cdot\left(p_{2} \cdot e^{p_{1} \cdot t_{1}}-p_{1} \cdot e^{p_{2} \cdot t_{1}}\right)
$$

In case when $\mathrm{p} 1 \leq \mathrm{p}_{2}$ it is possible to use the following equation for this circuit:

$$
t_{1}=\frac{\ln \left(U_{k}-U_{C T}\right)-\ln \left(-\frac{U_{k} \cdot p_{2}}{p_{1}-p_{2}}\right)}{p_{1}}
$$

For normal operation of an electronic circuit of control it is necessary that

$$
t_{1} \leq t_{\text {turn-on } \min }=0,75 \cdot t_{\text {turn-on }}
$$

The equation of a transmission process at the second stage looks as follows:

$$
u_{k}=i_{k} \cdot R_{k}+L_{k} \cdot \frac{d i_{k}}{d t}+u_{C}
$$

where $i_{k}=C_{1} \cdot \frac{d u_{C}}{d t}+\frac{u_{C}}{R_{E}}$

Or after the corresponding transformations:

$$
\begin{aligned}
& \frac{d^{2} u_{C}}{d t^{2}}+\left(\frac{R_{E}}{L_{k}}+\frac{1}{R_{E} \cdot C_{1}}\right) \cdot \frac{d u_{C}}{d t}+u_{C} \cdot \frac{1}{L_{k} \cdot C_{1}} \cdot\left(1+\frac{R_{k}}{R_{E}}\right)= \\
& =\frac{U_{k}-U_{C T}}{L_{k} \cdot C_{1}}
\end{aligned}
$$

In case when $t=0, U_{C}(0)=U_{C T}, I_{K}(0)=\frac{U_{K}}{L_{k} \cdot\left(p_{1}-p_{2}\right)}$.

$$
\cdot\left(e^{p_{1} \cdot t_{1}}-e^{p_{2} \cdot t_{1}}\right)
$$

Using known calculation techniques of transmission processes of electric circuits [11], we obtain:

$$
\begin{gathered}
u_{C}=U_{K} \cdot k-A \cdot e^{p_{1}^{\prime} \cdot t}+\left(A+U_{C T}-U_{K} \cdot k\right) \cdot e^{p_{2}^{\prime} \cdot t_{1}} \\
\text { where } A=\frac{1}{p_{1}^{\prime}-p_{2}} \cdot\left[p_{2}^{\prime} \cdot\left(U_{C T}-U_{K} \cdot k\right)+\frac{I_{K}(0)}{C_{1}}\right] \\
k=\frac{R_{E}}{R_{E}+R_{k}} ; \\
p_{1,2}^{\prime}=-\alpha \pm \sqrt{\alpha^{2}-\frac{1}{\kappa \cdot L_{k} \cdot C}} \\
\alpha=\frac{1}{2} \cdot\left(\frac{R_{k}}{L_{k}}-\frac{1}{R_{E} \cdot C_{1}}\right) .
\end{gathered}
$$

So, in a stable condition the voltage on the condenser $C_{1}$ is equal to $U_{K} \cdot k=U_{0}$

Practically the time of a condenser charge is determined from the equation (10) assuming that $U_{K} \cdot k=U_{0}$. However, if $p_{2}^{\prime}>p_{1}^{\prime}$, this time can be determined from the equation:

$$
t_{2}=\frac{\ln \frac{A}{0,05 \cdot U_{0}}}{-p_{1}^{\prime}}=\frac{\ln 0,95 \cdot U_{0}-\ln A}{p_{1}^{\prime}}
$$


In this case the full time of a condenser charge will be $t_{\text {charge }}=t_{1}+t_{2}$.

When a contactor is turned off, a condenser $C_{1}$ starts discharging through an open semiconductor key VT2 and a resistor $R_{6}$, and it finishes when the voltage on the condenser occurs and it is equal to the voltage of a regulator breakdown VD1.

The equation of a transmission process in this case looks like that:

$$
R_{E} \cdot \mathrm{C}_{1} \frac{d u_{C}}{d t}+u_{C}=0
$$

When $t=0-U_{0}=U_{K} \cdot k$. Then

where $\tau=R_{\mathrm{E}} \cdot C_{1}$.

$$
u_{C}=U_{K} \cdot k \cdot e^{-. t / \tau}
$$

The time of a condenser discharge $\left(t_{\text {disch }}\right)$, until the voltage is $U_{\mathrm{CT}}$, will be determined from the following equation:

$$
t_{\text {disch }}=\tau \cdot \ln \frac{U_{K} \cdot k}{U_{C T}}
$$

For the normal operation of a circuit controlled by a contactor it is necessary that the following in-equation to be carried out:

$$
t_{\text {disch }} \leq t_{\text {turn-off max }}=1,25 \cdot t_{\text {turn-on }}
$$

In this case $C_{1}=\frac{t_{t u r n-o f f \max }}{R_{E} \cdot \ln \frac{U_{K} \cdot k}{U_{C T}}}$

For reducing over-voltage by the current of an input circuit of optron thyristor VS1 it is recommended to fulfill a stipulation $\frac{U_{K} \cdot k}{U_{C T}} \leq(2 \div 3)$. In this case the stipulation will be fulfilled at which a condenser discharge $C_{1}$ with the help of a transistor key VT1 (fig. 1) will occur only in case of full transmission of current to the by-passing SK, i.e. the conditions, at which a reliable arcless commutation of a circuit at a contactor cutoff will be provided.

For reducing the influence of a condenser, turned on in parallel with the coil of an electromagnet, on a contactor operation it has been proposed by the authors to change the parameters of the base coil in such a way that an import power of a circuit of control could remain unchanged:

$$
\frac{U_{\mathrm{KB}}^{2}}{R_{\mathrm{KB}}}=\frac{U_{\mathrm{KB}}^{2}}{R_{\mathrm{K}}+R_{\mathrm{E}}}=P_{\mathrm{KB}}
$$

where $R_{\mathrm{KB}}, P_{\mathrm{KB}}$ - the resistance of a coil and the power of control of a base contactor respectively;

$R_{\mathrm{K}^{-}}$changed resistance of a coil;

$R_{\mathrm{E}^{-}}$equivalent resistance of a circuit which by-passes a condenser.

$R_{\mathrm{E}}$ та $R_{\text {Кв }}$ are determined in the following way:

$$
R_{\mathrm{E}}=\frac{U_{C}}{U_{\mathrm{K}}} \cdot R_{\mathrm{KB}}=k \cdot R_{\mathrm{KB}}
$$

As $R_{\mathrm{KB}}=R_{\mathrm{K}}+R_{E}$ then

$$
R_{\mathrm{K}}=R_{\mathrm{KB}} \cdot(1-k)
$$

The power on the changed coil:

$$
P_{\mathrm{K}}=P_{\mathrm{KB}} \cdot(1-k)
$$

In case of using a base contactor without changes the power in the coil would be $(1-k)^{2}$ times lower than in the preceding case:

$$
P_{\mathrm{y}}=P_{\mathrm{K} B} \cdot(1-k)^{2}
$$

So, the correlations obtained allow to calculate all the processes occurring in the circuit of electromagnetic drive and to choose the parameters of its main elements rationally.

\section{THE RESULTS OF CALCULATING THE PARAMETERS OF THE ELEMENTS OF AN ELECTROMAGNETIC DRIVE CIRCUIT}

The calculation values of the main parameters of the elements of an electromagnetic drive circuit, participating in

\begin{tabular}{|c|c|c|c|c|c|c|c|c|c|c|c|c|c|}
\hline \multirow[b]{2}{*}{$\begin{array}{c}I_{\text {NOM }}, \\
\boldsymbol{A}\end{array}$} & \multirow[b]{2}{*}{$\begin{array}{c}U_{\text {NOM }}, \\
\boldsymbol{V}\end{array}$} & \multicolumn{12}{|c|}{ Parameters of the electromagnetic circuit } \\
\hline & & $\begin{array}{c}U_{K}, \\
\boldsymbol{V}\end{array}$ & $k$ & $\begin{array}{c}R_{K}, \\
\text { Ohm }\end{array}$ & $\begin{array}{c}R_{E} \\
\text { Ohm }\end{array}$ & $\begin{array}{c}P_{K}, \\
W\end{array}$ & $\begin{array}{c}U_{0,} \\
\boldsymbol{V}\end{array}$ & $\begin{array}{c}U_{C T,}, \\
\boldsymbol{V}\end{array}$ & $\begin{array}{l}C_{l}, \\
\boldsymbol{u F}\end{array}$ & $\begin{array}{c}T_{\text {disch, }} \\
\boldsymbol{s}\end{array}$ & $\begin{array}{c}t_{1}, \\
s\end{array}$ & $\begin{array}{c}t_{2}, \\
s\end{array}$ & $\begin{array}{l}t_{\text {charq, }} \\
\boldsymbol{s}\end{array}$ \\
\hline $\begin{array}{l}100, \\
160\end{array}$ & \multirow{4}{*}{ 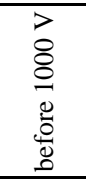 } & \multirow{4}{*}{ తి } & \multirow{4}{*}{$\overrightarrow{0}$} & 2562 & 284.47 & 15.3 & \multirow{4}{*}{22} & \multirow{4}{*}{9} & 394 & 0,1 & 0,053 & 0,24 & 0,293 \\
\hline 250 & & & & 1613.3 & 179.2 & 24.3 & & & 858.25 & 0.138 & 0.074 & 0.332 & 0.406 \\
\hline 400 & & & & 1089 & 1210 & 36 & & & 1617.75 & 0.175 & 0.0985 & 0.424 & 0.522 \\
\hline 630 & & & & 613.53 & 68.17 & 63.9 & & & 3897 & 0.237 & 0.111 & 0.8 & 0.911 \\
\hline
\end{tabular}
the commutation process of a completely controlled power $\mathrm{SK}$, are presented in table 1 . The calculations have been

\begin{tabular}{|c|c|c|c|c|}
\hline $\begin{array}{ll}\text { Parameters } & \text { Rat. current, } A \\
\end{array}$ & 100,160 & 250 & 400 & 630 \\
\hline Coil loss, W & 17 & 27 & 40 & 71 \\
\hline Coil resistance $R_{\mathrm{K} B}$ at $U_{\mathrm{y}}=220 \mathrm{~V}, \mathrm{Ohm}$ & 2847 & 1792.6 & 1210 & 618.7 \\
\hline Coil inductance $L_{K B}, \mathrm{H}$ & 28.5 & 18 & 12.1 & 6.817 \\
\hline Responce time, $\mathbf{s}$ & \multirow{3}{*}{$\begin{array}{l}0.18 \\
0.08\end{array}$} & \multirow{3}{*}{$\begin{array}{l}0.28 \\
0.11\end{array}$} & \multirow{3}{*}{$\begin{array}{l}0,40 \\
0.14\end{array}$} & \multirow{3}{*}{$\begin{array}{l}0.55 \\
0.19\end{array}$} \\
\hline When turned-on & & & & \\
\hline When disconnected & & & & \\
\hline
\end{tabular}
carried out according to the formulae (18) - (20), (13) - (16), (4) - (7), (10), (11). The contactors of the series КТП6000 were used as a base contactor. The main parameters of a circuit of their electromagnetic drive are given in table 2 [12].

TABLE I

TABLE II.

The analysis of the calculation results shows that calculation parameters of the elements of an electromagnetic drive circuit provide reliable operation of the circuit of controlling the commutation of the completely controlled 
A.Soskov, Ya.Forkun, O.legorov, Yu. Kolontaevsky Вип.56, №03.

$\mathrm{SK}$ in the whole range of nominal currents contactors using the contactless method. At each of the proposed nominal currents of a base contactor the charging time of a condenser $\mathrm{C}_{1}$ up to the voltage $\mathrm{U}_{\mathrm{CT}}$ in case of its turning on is lower than the minimum time of turning on a contactor and the time of discharge in case of turning off is always higher than the maximum time of cutting off a contactor. However, the dimensions and cost of a condenser $C_{1}$ despite its rather high capacity, will be inconsiderable, as we use an electrolytic condenser with low voltage (not higher than $25 \mathrm{~V}$ ).

Calculation methods as well as calculation parameters of a current transformer and the circuit of controlling the commutation of a completely controlled SK for the range of nominal currents $(100-130 \mathrm{~A})$ is presented in the work [5].

Calculation methods of overload capacity of a completely controlled SK as well as overloading limiter are presented in [13], where it is shown that power semiconductor devices performing the role of SK in hybrid contactors can be applied without coolers using natural cooling. Providing of allowable level of overloading lower than $2,5 \cdot U_{\text {NOM }}$ can be achieved due to the turned on series-parallel low power varistors with the corresponding mass and cost.

\section{EXPERIMENTAL RESEARCH OF ELECTROMAGNETIC DRIVE OF THE PROPOSED CONTACTORS}

The aim of the research is to determine such important for the analysis of the work of an electromagnetic drive parameters as the value of a contactor turning on time $t_{\text {turn-on, }}$ a condenser charging time $C_{1} \cdot t_{\text {charg }}$ at turning on a contactor and the time of its discharging $t_{\text {disch }}$ at turning off. The researches have been carried out using a special installation, the electrical circuit of which is shown in figure 3.

The originality of the experiment is that in the course of the research a base contactor КТП6000 with the nominal current $250 \mathrm{~V}$ without any changes has been used.

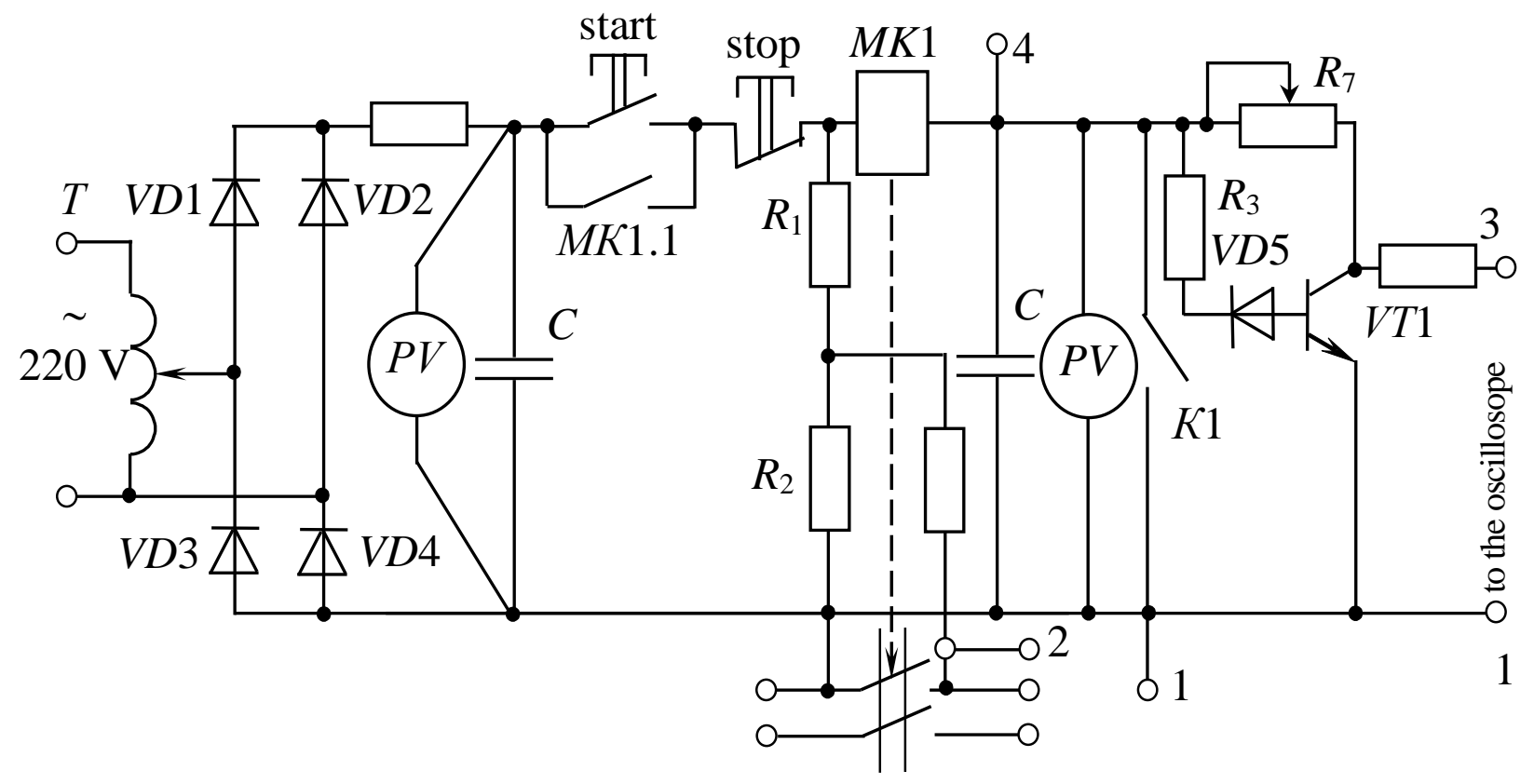

Fig. 3. Electrical circuit of the acting installation

Furthermore, operating conditions of electromagnetic drive of this contactor were the same as in the research, given in sections 4 and 5 for the same contactor. It has been achieved due to the following conditions:

$$
\begin{gathered}
\frac{U_{\mathrm{KB}}^{2}}{R_{K \mathrm{~B}}}=\frac{U_{\mathrm{KB}}^{2}}{R_{\mathrm{K}}+R_{E}}=P_{\mathrm{KB}} ; \\
U_{K E}=\gamma \cdot U_{K B} ; \\
k=\frac{R_{E}}{R_{K}+R_{E}}=0,1 ; \\
P_{\mathrm{K}}=P_{\mathrm{KB}} \cdot 0.9 ; \frac{U_{C T}}{R_{E}}=\frac{U_{C T E}}{R_{E}},
\end{gathered}
$$

Where $U_{K B}=220 \mathrm{~V} ; P_{K B}=27 \mathrm{~W}$

$$
\begin{gathered}
P_{\mathrm{K}}=24.3 \mathrm{~W} ; \\
\gamma \approx \frac{1}{U_{\mathrm{KB}}} \cdot \sqrt{P_{\mathrm{KB}} \cdot\left(R_{\mathrm{KB}}+R_{E}\right)}=1.054 ;
\end{gathered}
$$

$$
U_{K E}=231,92 \mathrm{~V} ; R_{E}=199.2 \mathrm{Ohm} ;
$$

$U_{C I E}=10 \mathrm{~V}^{-}$corrected values of controlling voltage, equivalent to the resistance, the voltage of the voltage regulator stabilization $V D 5$ respectively.

In this case the value a condenser capacity remained unchanged and equal to $858 \mathrm{uF}$.

Time measuring was carried out with the help of dualpattern digiscope, and the terminals 1 and 2 were used for measuring $t_{\text {turn-on }}$, and the terminals 1 and 4 - for measuring $t_{\text {disch }}$ and $t_{\text {charg. }}$. Measuring of $t_{\text {turn-on }}$ for the base contactor was carried out when $U_{K}=250 \mathrm{~V}$ and closed contacts $K 1$.

The voltage measuring was carried out with the help of a digital voltmeter. The results of comparison of experimental and calculation values of the parameters research are presented in table 3. Furthermore, calculations were carried out according to the same methods as in section 5 . 
EXPERIMENTAL AND CALCULATION VALUES OF THE MAIN PARAMETERS OF AN ELECTROMAGNETIC DRIVE.

\begin{tabular}{|c|c|c|c|c|c|c|c|c|c|c|c|c|c|c|c|}
\hline \multirow{2}{*}{$\begin{array}{c}\mathbf{I}_{\text {NOM }}, \\
\mathbf{A}\end{array}$} & \multirow{2}{*}{$\begin{array}{l}\mathbf{R}_{\mathrm{KB}} \text {, } \\
\text { Ohm }\end{array}$} & \multirow{2}{*}{$\begin{array}{c}\mathbf{R}_{\mathrm{E}} \\
\text { Ohm }\end{array}$} & \multirow{2}{*}{$\begin{array}{c}\mathbf{U}_{\text {CTE, }}, \\
\mathbf{V} \\
\end{array}$} & \multicolumn{2}{|c|}{ UoE, V } & \multirow{2}{*}{$\begin{array}{l}\delta, \\
\%\end{array}$} & \multicolumn{2}{|c|}{ t turn-on, $s$} & \multirow{2}{*}{$\begin{array}{l}\mathrm{g}, \\
\%\end{array}$} & \multicolumn{2}{|c|}{$\mathbf{t}_{\text {charq, }} \mathbf{S}$} & \multirow{2}{*}{$\begin{array}{l}\delta, \\
\%\end{array}$} & \multicolumn{2}{|c|}{$\mathbf{t}_{\text {disch, }} \mathbf{S}$} & \multirow{2}{*}{$\begin{array}{l}\delta, \\
\%\end{array}$} \\
\hline & & & & Exp. & Pay. & & Exp.. & Base & & Exp.. & Pay. & & Exp. & Pay & \\
\hline$\stackrel{\overbrace{}}{\sim}$ & ภ & ๙ุ? & 음 & $\ddot{\sim}$ & $\frac{\partial}{\ddot{\lambda}}$ & $\stackrel{+}{+}$ & $\begin{array}{l}\bar{\infty} \\
\text { ஸ̦ } \\
0\end{array}$ & 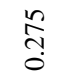 & $\underset{\sim}{\stackrel{\sim}{+}}$ & 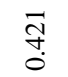 & ¿্ণ & \begin{tabular}{l}
$\infty$ \\
\multirow{2}{+}{} \\
+
\end{tabular} & $\frac{0}{0}$ & $\frac{8}{0}$ & : \\
\hline
\end{tabular}

The analysis of the results given in table 3 showed a high level of coincidence of experimental and calculation values of the investigated parameters. The maximum error does not exceed $6,1 \%$ and it is quite acceptable for the engineering calculation methods. These researches also showed that it is not efficient to increase the value $k$ higher than 0,1 because of possible failure of a drive operation.

\section{THE DISCUSSION OF THE RESEARCH RESULTS}

The application of the hybrid contactors of an electronic circuit control by an electromagnetic drive current, presented in the schemes, allows to create a series of positive characteristics, increasing their competitiveness. It can be achieved by the introduction, in parallel with a drive coil, of a special electronic circuit of turn-on of a completely controlled power SK, containing a condenser, setting the time and a controlled transistor key, in an output circuit of which a lowpower optron thyristor is turned on. In parallel with the mentioned condenser an auxiliary transistor key is connected, providing a discharge in case of commutation current flow from the main contactors circuit to SK circuit with the help of an additionally introduced auxiliary transformer coil. This circuit provides a reliable contactless commutation of a power SK in all operating conditions of a contactor. Additional positive characteristics, obtained as a result of using technical solutions, proposed by the authors, are clearly defined in section 3 and were confirmed with the results given above the theoretical and experimental researches.

The weak point of these contactors is the fact that the introduction of a charged condenser in parallel with a drive coil decreases the control power of this coil and consequently, complicates the process of connecting a contactor. As a result, to minimize this influence it is proposed to limit the voltage value on this condenser at the level $0,1 \cdot U_{K}$.

With the existing base of elements, the above mentioned complicates the application of this contactor when the voltage level of control is lower than $110 \mathrm{~V}$. But this weak point is compensated with the achieved positive characteristics.

Carried out research of nonstationary processes, occurring in the contactors circuits in case of commutation, allowed to develop the methods of calculating the main elements of an electronic circuit of a contactor. suitable for engineering calculations.

Furthermore, it has been shown that the charging time of a condenser, setting the time up to the level of voltage providing the turn-on of a low-power optron thyristor when a contactor is turned on, shouldn't be higher than the value of the minimum time of its turn-on, and the discharge time of this condenser when turning off shouldn't be lower than the maximum time of turning off a contactor.

It has been also shown that the consumption capacity in controlling circuits of the proposed contactor should be equal to the same capacity of a base contactor.

The results of calculations and experimental researches, presented in the article as well as in the works published by the authors before, show real possibility of creating hybrid contactors of direct current with the proposed principle of operation, rated for currents $100630 \mathrm{~A}$ and voltage up to $1000 \mathrm{~V}$.

The results obtained may be applied when developing contactors, which can be efficiently used in hard maintenance conditions with frequent engine starts, for example, in electric transport, in crane equipment, in rolling production of metallurgical plants etc, as well as in electrical systems of alternative electric power industry in conditions of increased explosion and fire safety requirements. Furthermore, their positive characteristics, mentioned above, considerably increase their competitiveness.

\section{CONCLUSIONS}

It has been substantiated that the proposed hybrid contactors as compared with the existing ones have the following advantages:

Increased reliability of operation provided by excluding of unreliable contact circuit on the basis of current relay from the power SK control circuit and the possibility of emergency restart of a power SK when disconnecting the contactor is completely excluded;

Economical operating conditions of the elements of a contactor electronic circuit;

The influence of a net voltage on the elements of a control circuit is excluded;

The dimensions, mass and cost are reduced due to essential simplification of a control circuit (time relay and a large non-process current relay are excluded, the connections between the elements are simplified);

The parameters and operating conditions of an electronic control circuit do not depend on a net voltage and are determined only by the current which is turned off and it allows to apply the proposed technical solutions also for creating hybrid contactors for the voltage higher than $1000 \mathrm{~V}$.

The lack of a commutation zone with an arc increases its commutation wear resistance as well as allows to use it in conditions of explosion and fire safety requirements.

It has been stated that for providing reliable commutation of a circuit it is necessary that the time of a condenser charging, setting the time up to the level of voltage and providing turn-on of a low-power optron thyristor in case of turning on a contactor, shouldn't be above the value of minimum time of its turn-on and the discharge time of this condenser in case of turn-off, shouldn't be below the maximum time of turning off a contactor.

The developed methods of calculating the main elements of a contactor electronic circuit allows to make calculations with sufficient accuracy for engineering calculations and it is confirmed with the results of experimental researches. The research results show the real possibility of creating competitive hybrid contactors of direct current with the 
A.Soskov, Ya.Forkun, O.legorov, Yu. Kolontaevsky Вип.56, №03.

proposed principle for the current $100-630 \mathrm{~A}$ and the voltage up to $1000 \mathrm{~V}$.

\section{REFERENSES}

[1] A.G. Soskov. Low voltage hybrid contactors with improved technical and economic characteristics [Text] : monograph / A.G. Soskov, N. O. Sabalayeva; O. M. Beketov National Academy of Urban economy in Kharkiv : HNAMG, 2012. - 268 p.

[2] Lu Qi, Guogang Zhang, Iingcun Liu, Zheng Qin, Yingsan Gend, Jianhua Wang. Researching on integrated design of vacuum switch based on permanent magnetic actuator for DC contactor // Materials of 4th International Conferens of Electric Power Equipmentswitching Technology (ICEPE). China, Xian, 2017, Oct. 22 - Oct. 25.

[3] Yang Gao, Xiaoguang Wei, Zhiyuan He, Longlong Chen, Yunhai Shan. A hybrid circuit breaker for DC-application. IEEE First International Conference. - 2015. - P. 187 - 192, doi: 10.110 /ICDCM.2015.7152036

[4] Hassanpoor, A.; Hafner, J.; Jacobson, B. Technical Assessment of Load Commutation Switch in Hybrid HVDCBreaker. Power Electronics, IEEE Transactions on Year: 2015, Volume: 30, Issue: 10 Pages: $5393-5400$.

[5] A. G. Soskov, N. O. Sabalayeva, Ya. B. Forkun, M. L. Glebova Development Of Principles And Methods Of Calculation Of Direct Current Hybrid Contactor // Eastern-European Journal of Enterprise Technologies. - 2018. - Vol. 2/5 (92). P. 48-63.
[6] Hybrid DC electromagnetic contactor: patent no. 7079363 B2 USA. №10/404061 field: 2.04.2003 ; date of patent 18.07.2006

[7] Patent no. 7538990 B2USA, Int. Cl. H02H 3/00, H02H 7/00 High voltage contactor hybrid without a DC arc break[Text] /BelisleF.C. CarterE.A. MetzlerM.W., Wavering J.T. (USA). - 11/638984 ; field 14.12.2006; date of patent 26.05.2009

[8] Patent no. US4992904A. Int. Cl. H01H9/54, H02H3/087. Hybrid contactor for DC airframe power supply [Text] / William M. Spencer, Joseph S. (USA). - 07/436.021 ; field: 14.11.1989; date of patent 12.02.1991.

[9] Patent no. 129577 Hybrid bipolar DC electromagnetic contactor (A.G. Soskov, N. O. Sabalayeva, M. L. Glebova, S. Kotelevets.) application u 2018 01968, date submission of the application 12.11.2018, date of patent validity 12.11 .2018 , bulletin №21. (Patent no.127577).

[10] . Patent no.127034 Hybrid bipolar DC contactor (A.G. Soskov, N. O. Sabalayeva, Ya. B. Forkun, Ye. S. Savchuk) application u 2018 01995, date submission of the application 26.02.2018, date of paten validity 10.07.2018, bulletin №13.

[11] . G. V. Zeveke, P. A. Ionkin, A. V. Netushyl, S. V. Strakhov. Bases of the theory of chains: textbook -5 edition. Moscow: $1990 .-528$ p.

[12] . G. V. Mohylevskyi Low voltage hybrid electric appliances. Moscow : energy atom publishing house, 1986. -232 p.

[13] Soskov A. G. Methods of overvoltage limitation in modern DC semiconductor switching apparatus and their calculation [Text] / A G. Soskov, N. O. Sabalayeva, Ya. B. Forkun, M. L. Glebova Eastern-European Journal of Enterprise Technologies. - 2016. - Vol. 3/8 (81). P. 4-9

\section{Принципи та методи розрахунку гібридних контакторів постійного струму, що керуються струмом електроприводу}

\section{А.Г. Сосков}

Харківський національний університет міського господарства ім. О.М.Бекетова, Україна

\section{О.Б. Єгоров}

Харківський національний університет міського господарства ім. О.М.Бекетова, Україна
Я.Б. Форкун

Харківський національний університет міського господарства ім. О.М.Бекетова, Україна

\section{Ю.П. Колонтаєвський}

Харківський національний університет міського господарства ім. О.М.Бекетова, Україна

Показано, що принцип керування струмом електромагнітного приводу гібридного контактора постійного струму реалізовано шляхом введення послідовно з котушкою приводу спеціальної електричної схеми керування включення силового НК, що містить конденсатор, що задає час, та керований малопотужний транзисторній ключ, в вихідне коло якого ввімкнений малопотужний оптронний тиристор, при чому паралельно вказаному конденсатору вмикається допоміжний транзисторній ключ, який забезпечує за допомогою додатково введеної вторинної обмотки трансформатора струму його розряд при перетіканні комугаційного струму з кола головних контактів в коло силового напівпровідникового ключа.

Визначені особливості процесів заряду та розряду конденсатора, що задає час, в різних режимах роботи контактора. При цьому було встановлено, що для забезпечення надійної комутації кола необхідно, щоб час заряду конденсатора, що задає час, до рівня напруги, що забезпечує включення малопотужного оптроного тиристора при вмиканні контактора, не повинен перевищувати значення мінімального часу його вмикання, а час розряду цього конденсатора при вимиканні не повинен бути меншим, ніж максимальний час відмикання контактора. Це дозволяє обгрунтовано підходити до визначення параметрів елементів, що забезпечують надійну комутацію контактора.

В результаті проведених досліджень також було показано, що пропоновані гібридні контактори завдяки введенню керування струмом електромагнітного приводу та введенню нових зв'язків порівняно з існуючими мають властивості, що підвищують їх конкурентоспроможність. Зокрема в них підвищена надійність роботи, зменшені габарити та вартість, покращені їх виробничотехнологічні показники, розширена область застосування.

Прикладним аспектом використання одержаного наукового результату є можливість створення конкурентоспроможних надійних

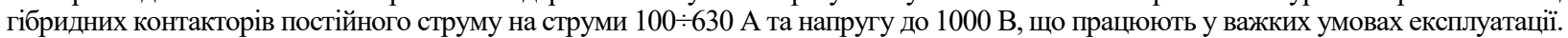

Ключові слова - гібридний контактор, постійний струм, головні контакти, силовий напівпровідниковий ключ, керування струмом, електромагнітний привод. 